ノ -

苗断片和よび塊根切片を利用したサツマイモ立枯病抵抗性の簡易検定法

井内美砂 ${ }^{1 ）}$ ・ 川村泰史 ${ }^{2)}$ ・ 小巻克巳 ${ }^{3)}$

${ }^{1)}$ 徳島県農業大学校, 名西郡石井町, $\overline{7} 779-3233$

2) 徳島県立農林水産総合技術センタ一農業研究所, 名西郡石井町, $\overline{\mathbf{T}} 779-3233$

3)作物研究所, つくば市, 干 305-8518

\title{
Rapid and Efficient Methods for Evaluation of Resistance to Streptomyces ipomoea Inoculating to Small Vine Cuttings and Storage Root Slices in Sweetpotato
}

Misa Iuchi ${ }^{1)}$, Hirofumi Kawamura ${ }^{2)}$ and Katsumi Komaki ${ }^{3)}$

1) Tokushima Agricultural College, Ishii 779-3233, Japan

2) Agriculture Institute, Tokushima Agriculture, Forestry and Fisheries Technology Center, Ishii 779-3233, Japan

${ }^{3)}$ National Institute of Crop Science, Tsukuba 305-8518, Japan

キーワード

サツマイモ, Streptomyces ipomoea, サッマイモ立枯病, 簡易検定, 苗断片, 塊根切片

\section{1. はじめに}

サツマイモ生産地帯, 特に青果用の生産地帯では, サ ッマイモ立枯病の被害が甚大になっている. わが国で本 病害の発生が認められるようになった 1970 年代には「か いよう病」と呼ばれ, Fusarium solani f. sp. radicicolaによ るものとされていたが，その病原性に疑問が持たれ，ま た米国で発生している Soil rot に症状が酷似していると ころから，現在では放線菌である Streptomyces ipomoea によることが明らかにされている（小川1984）.

サツマイモ立枯病は, 挿苗直後から苗表面や苗の節か ら出現する不定根を加害するため, 活着不良となって初 期生育が遅延し, 甚だしい場合は苗が枯死し, 収量の低 下をもたらす。 また, 塊根肥大期には表面に黒いかさぶ た状の病変を生じさせ，塊根品質を著しく低下させる。

わが国での発生当初は, マルチ資材を利用した栽培を 行う青果用サッマイモで大きな問題となっていたが, 最 近では加工用（蒸切干し用）サッマイモでもマルチ資材 の普及に伴い発生が認められるばかりか, 露地栽培でも 被害が報告されるようになってきている.

現在の主要な青果用执よび加工用品種は本病害に感受 性であり，抵抗性であるとされている「ベニアズマ」で も発生が認められることからクロルピクリンによる土袞 消毒が行われている. しかし, 環境問題, 周辺地域の住 民不安などにより，できる限り土壌消毒は行わないこと

編集委員 : 渡邊和男

2004 年 5 月 11 日受領 2004 年 12 月 24 日受理

Correspondence: riemon@affrc.go.jp
が望まれている.

このため, 本病害の発生地帯では抵抗性を付与した高 品質サッマイモの育成が求められ, 育種的な対応が行わ れているところである.「ベニアズマ」は 1980 年に育成 されたわが国初の抵抗性品種であるが（坂本ら 1980）, 近年発病が目立つよらになってきて扣り,さらに抵抗性 を強化した品種の育成が切望されている. 現在, 抵抗性 の検定は独立行政法人農業・生物系特定産業技術研究機 構作物研究所に和けるサッマイモ育種プログラムの中で 実施され, 激発圃場に苗を植え, 約 2 ヶ月後に現れる苗 の萎调および病斑の発現程度と塊根での黒い病変の出現 程度を総合して発病程度を判定している. しかし, 気象 条件, 土壤条件などが年次によって変動するため, 発病 が安定せず，さらに夏季の高温時の調査であるため，労 力的な負担も大きい，そこで，簡易検定法として，苗へ の接種あるいは人工的に作成した污染土による方法が検 討されたがこれまでのところ実用的に利用可能な方法は ない.

そこで，本報では実用的に利用可能なサッマイモ立枯 病の簡易でかつ精度の高い検定法の開発のために, 苗抒 よび塊根を用いて行った接種検定の結果をサッマイモ立 枯病激発圃場で複数年栽培して得られた抵抗性検定結果 と比較し，育種に括ける適用の可否について論じた。

\section{2. サツマイモ立枯病菌に対する苗の反応の違いを 利用した検定}

サッマイモの苗の先端約 $5 \mathrm{~cm}$ の細い部分を除いた後, はさみで長さ約 $3 \mathrm{~cm}$ ずつに切り, 検定の対象とした. 
サッマイモ立枯病菌は, 徳島県鳴門市の激発戋場から 1991 年に分離した T-221 株を用いた. 菌の調製は, ISP-2 液体培地 $(0.4 \%$ Yeast Extract， $1.0 \%$ Malt Extract， 0.4\% Glucose, $\mathrm{pH}$ 7.3) で $2 \sim 3$ 日間 $140 \mathrm{rpm}$ で振盪培養した菌 体を, $1 \mathrm{~mm}$ 目のふるいでろ過し, $5000 \sim 6000 \mathrm{rpm}$ で遠 心分離後, 菌体の重量を測定し, ISP-2 液体培地で所定 の濃度に希釈することによって行った.

接種から 7 日後に病斑数を調査し, 発病度を病斑数が 0 個の時 $0,1 \sim 2$ 個の時 $1,3 \sim 9$ 個の時 2, 10 個以上の 時 3 , 全体が黒変した時 4 とし, 試験区ごとに平均値を 算出した.

\section{（1）接種方法}

感受性の「高系 14 号」と抵抗性の「ベニアズマ」を用 いた. 接種の方法としては, 苗断片を培土に挿した後, 菌 体懸濁液を注ぐ方法执よび苗断片を菌体懸濁液に数秒間 浸した後, 培土に挿す方法の 2 種類を用い, 接種する菌 体の濃度は 50 抢よび $100 \mathrm{~g} / 1$, 培土に接種する菌体懸濁 液の量は 1 抢よび $2 \mathrm{ml}$ ，培土はバーミキュライトまたは 砂とした。接種後は苗断片を挿した培土は128 穴のセル トレイに詰め, ポリエチレンフィルムで扮扮った育苗箱 をかぶせて湿度を保ち, 温度を $30^{\circ} \mathrm{C}$, 暗黒状態で培養し た. 試験区は各区 8 苗断片とした.

培土にバーミキュライトを用いた区では, 接種の方法, 菌体濃度および菌体懸濁液の量にかかわらず，発病度が 高く, すべての区で「高系 14 号」が「ベニアズマ」を上 回ったが，砂を用いた区では，全般に発病度が低いだけ でなく，接種方法によっては抵抗性である「ベニアズマ」 の方が発病度が高くなる場合があった（図 1)。これは, 砂の方が乾燥しやすかったため，水分のばらつきが大き かったことが原因の一つであると考兄られた.

このように, 発病の安定性, 接種の簡便さ和よび使用 する菌体の量を総合して，バーミキュライトを培土に用 い, 苗断片を $50 \mathrm{~g} / 1$ の菌体懸濁液に数秒間つけて培土に 挿す方法が適当と考光られた。

\section{（2）培養温度}

培養温度を $20,25,30$ 抢よび $35^{\circ} \mathrm{C}$ と, 各区 10 苗断 片を $50 \mathrm{~g} / 1$ の菌体懸濁液に数秒間つけてからバーミキュ ライトに挿す方法で接種した.

発病は $25^{\circ} \mathrm{C}$ 以上で認められた (表 1). 発病株率は $30^{\circ} \mathrm{C}$ まで増加し, $35^{\circ} \mathrm{C}$ でも同程度であったが, 発病度は $35^{\circ} \mathrm{C}$ で最も高かった。 また, 発病度は激発圃場での抵抗性が 低いもので高い傾向があった. 最も感受性であると判定 されている 89SB-71 での発病度が低かったのは苗がやや 老化し，硬化していたことがその原因であると考学られ る. 一方, 温度が高くなるにつれて培養中に腐敗する苗 断片が増加した. $35^{\circ} \mathrm{C}$ では品種によってはすべての苗 断片が腐敗する場合もあることから（表 1), 培養温度 は, $25^{\circ} \mathrm{C}$ から $30^{\circ} \mathrm{C}$ が適当と判断された。

（3）サツマイモ立枯病抵抗性が異なる品種·系統への適用 サッマイモ立枯病激発圃場（千葉県佐原市扣よび徳島 県石井町）での検定により抵抗性が異なると判定された

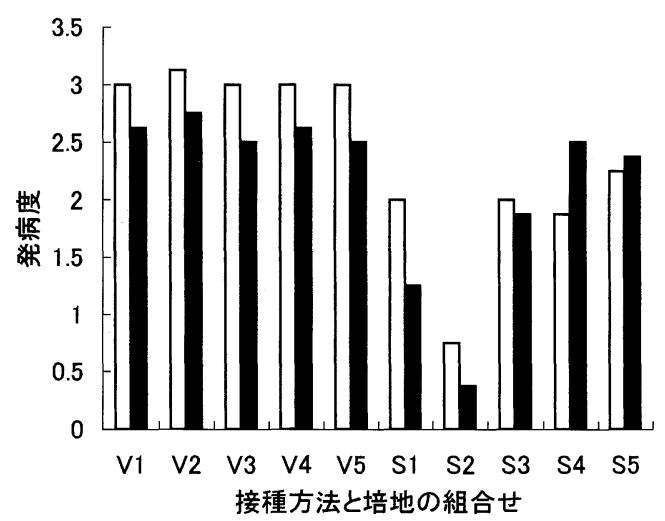

図 1. 苗断片へのサッマイモ立枯病菌の接種による発病度に対 する接種方法と培土の影響. (接種方法) 1 : 苗断片を培地 に挿苗後, $50 \mathrm{~g} / 1$ のサッマイモ立枯病菌懸濁液を $1 \mathrm{ml}$ 注 入, $2:$ 同 $100 \mathrm{~g} / 1$ を $1 \mathrm{ml}$ 注入, $3:$ 同 $50 \mathrm{~g} / 1$ を $2 \mathrm{ml}$ 注入, 4 : 苗断片を $50 \mathrm{~g} / 1$ の懸濁液に浸漬後培土に挿苗, 5 : 同 $100 \mathrm{~g} / 1$ 飞浸漬後挿苗. (培土の種類) V : バーミキュライ 卜, S : 砂. (品種) $\square:$ 高系 14 号, $\square:$ : ニアズマ

表 1. 苗断片に括けるサッマイモ立枯病の発病株率, 発病度及び腐敗に及ぼす培養温度の影響

\begin{tabular}{|c|c|c|c|c|c|c|c|c|c|c|c|c|}
\hline \multirow{2}{*}{ 品種 ${ }^{1)}$} & \multicolumn{4}{|c|}{ 発病株率 $(\%)^{2)}$} & \multicolumn{4}{|c|}{ 発病率 2,3$)$} & \multicolumn{4}{|c|}{ 腐敗率 (\%) } \\
\hline & $20^{\circ} \mathrm{C}$ & $25^{\circ} \mathrm{C}$ & $30^{\circ} \mathrm{C}$ & $35^{\circ} \mathrm{C}$ & $20^{\circ} \mathrm{C}$ & $25^{\circ} \mathrm{C}$ & $30^{\circ} \mathrm{C}$ & $35^{\circ} \mathrm{C}$ & $20^{\circ} \mathrm{C}$ & $25^{\circ} \mathrm{C}$ & $30^{\circ} \mathrm{C}$ & $35^{\circ} \mathrm{C}$ \\
\hline 90IDN-47(強) & 0 & 0 & 0 & - & 0.0 & 0.0 & 0.0 & - & 0 & 40 & 50 & 100 \\
\hline ベニアズマ(やや強) & 0 & 0 & 0 & - & 0.0 & 0.0 & 0.0 & - & 0 & 40 & 70 & 100 \\
\hline ベニコマチ (やや弱〜中) & 0 & 80 & 100 & 100 & 0.0 & 1.1 & 2.6 & 3.0 & 0 & 0 & 0 & 80 \\
\hline 高系 14 号 (やや弱) & 0 & 80 & 100 & 100 & 0.0 & 2.1 & 3.0 & 3.0 & 0 & 40 & 70 & 90 \\
\hline 89SB-71 (弱) & 0 & 80 & 100 & 100 & 0.0 & 1.6 & 2.6 & 2.8 & 0 & 0 & 0 & 10 \\
\hline
\end{tabular}

1) 括弧内は作物研究所の現地激発戋場（千葉県佐原市）で判定された抵抗性.

2) 腐敗した苗断片は発病株率拈よび発病度の算出では除外した. 一はすべての苗断片が腐敗し発病の有無・程度を判 定できなかったことを示す。

3) 発病度を病斑数が 0 個の時 $0,1 \sim 2$ 個の時 $1,3 \sim 9$ 個の時 2,10 個以上の時 3 , 全体が黒変した時 4 とし, 平均值 を算出した。 
表 2. サッマイモ立枯病抵抗性が異なる品種・系統の苗断片に 扣ける発病度

\begin{tabular}{lc}
\hline \multicolumn{1}{c}{ 品種 $^{1)}$} & 発病度 $^{2)}$ \\
\hline 90IDN-47 (強) & 0.3 \\
ベニアズマ(やや強) & 0.4 \\
九州 112 号(中) & 2.0 \\
ミナミュタカ(中) & 2.2 \\
春こがね (中) & 3.6 \\
ベニコマチ(やや弱〜中) & 3.0 \\
高系 14号(やや弱) & 2.8 \\
ヘルシーレッド(やや弱) & 3.4 \\
シロサッマ(やや弱) & 3.5 \\
タマユタカ(やや弱) & 3.7 \\
89SB-71(弱) & 4.0
\end{tabular}

1) 括弧内は作物研究所および徳島県立農林水産総合技術セン タ一農業研究所の激発戋場（千葉県佐原市扣よび徳島県石井 町）で判定された抵抗性.

2)表1に同じ.

11 品種・系統の苗断片を $50 \mathrm{~g} / 1$ の立枯病菌体懸濁液に数 秒つけ, バーミキュライトに挿し， $30^{\circ} \mathrm{C}$ で約 7 日間培養 して発病させた. 試験区は 1 区 10 苗断片， 2 反復とし た．発病度は，戋場検定による抵抗性が強いほど低かっ た．抵抗性が中である「春こが惝」で発病度が高かった のは，苗が細く，腐敗と立枯病による黒变との区別が困 難であったためである。

品種・系統による病斑の違いを図 2 に示す，感受性で ある「89SB-71」特よび「高系 14 号」では, 病斑は形成 層にまで達し，さらに内部へ広がったが，抵抗性である 「90IDN-47」では, 病斑は内部へ広がらず，かさぶた状に なって表皮で止まって扣り，菌への防御反応を反映して いると考光らる。.

\section{3. サツマイモ立枯病菌に対する塊根の反応の違い を利用した検定}

サッマイモ立枯病抵抗性が異なる 6 品種（表 3）を用 い, 塊根を流水でよく洗浄し, 両端を除いた後, $5 \mathrm{~mm}$ 厚 に切り, 検定の対象とした.

サッマイモ立枯病菌は農業研究センタ一病害虫防除部 マイコプラズマ病防除研究室が保存しているNo.9 の菌 株を用いた，菌の調整は，既述の方法で行った．まず予 備試験として, Moyer et al.（1984）の手法を基本として, サッマイモ立枯病の菌体 $2.3 \mathrm{~g}$ を $100 \mathrm{ml}$ の ISP-2 培地に 懸濁し， $1,000 \mathrm{ml}$ の滅菌砂に均一に散布した。 この上に 「ベニコマチ」を除く 5 品種の塊根を置床し, 容器をポリ エチレンラップで被覆して湿度を保つようにし, 暗黒・ 室温条件下で 14 日間培養して, 病斑の発現の有無を確 認した（図 3)。その結果，この方法で病斑の発現の品種 間差異を把握できると判断されたため, 接種方法および 培養温度について検討を加えた。

接種から 14 日後に塊根切片の切りロに形成されたカ

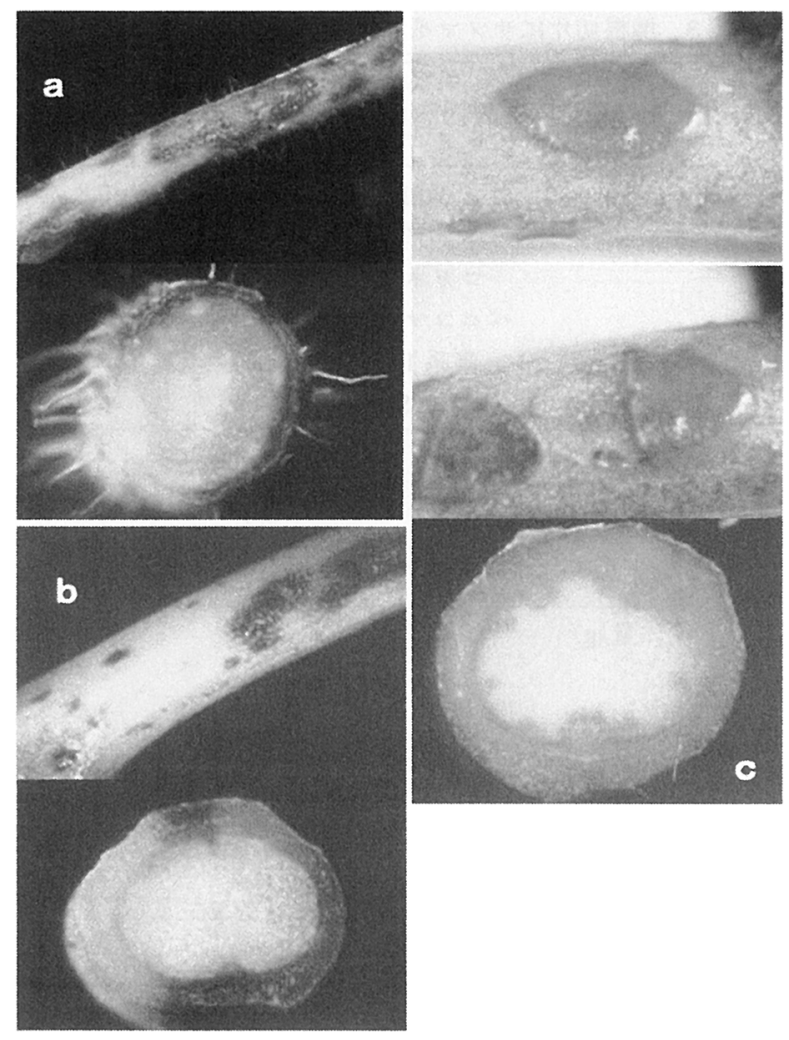

図 2. 苗断片にサッマイモ立枯病菌を接種したとき発現する病 斑の品種間差異. $\mathrm{a}: 89 \mathrm{SB}-71, \mathrm{~b}:$ 高系 14 号, $\mathrm{c}: 90$ IDN-47

ルスおよび菌体をナイロンネットで除去した後, 病斑面 積を調査し，発病度を塊根切断面の全体に対する病斑面 積の比率に応じて0（病斑がない）～9（全面が黒変また は腐敗）とし，試験区ごとに平均值を算出した。

培養温度を $25.0,27.5,30.0$ 扤よび $35.0^{\circ} \mathrm{C}$ の 4 水準, 菌体量を $0.0,0.5,1.0,2.0$ 抢よび $5.0 \mathrm{~g}$ の 5 水準，菌体を 懸濁する培地を蒸留水掞よび ISP-2 培地の 2 種類，培地 の量を 50 抢よび $100 \mathrm{ml}$ の 2 水準とし，これらを様々に 組み合わせて発病度を検定した. 総試験区数は 132 区で, 塊根切片は試験区当たり $3 \sim 4$ とした. 培養容器は密閉 可能なプラスチック容器とし, 培養中は密閉し, 暗黒条 件とした.

病斑は接種菌体量が $0.5 \mathrm{~g}$ からいずれの条件でも発生 し，腐敗は培養温度および培地の種類の影響が認められ た（表 3）。病斑预よび腐敗はほとんどの条件で有意な正 の相関を示し，「ベニアズマ」を除くとサッマイモ立枯病 抵抗性が強い注ど少なく, 病斑のみならず腐敗にもサッ マイモ立枯病菌が関与している可能性を強く示㖫した が，他の糸状菌等の関与も否定できないため，検定を行 ら場合はできるだけ腐敗が起こりにくい条件で実施する ことが必要であると考兄られた．蒸留水を培地に用いる と全く腐敗しなかったが, 蒸留水では抵抗性程度と発病 度に相関関係は認められなかったため, ISP-2 培地が培 地として適当であった．培養条件による品種ごとの腐敗 率を表 4 に示すが, 培養温度が $25.0^{\circ} \mathrm{C}$ では最も感受性で 
表 3. 塊根切片にサッマイモ立枯病菌を接種したときの発病度, 腐敗率および相互の相関係数

\begin{tabular}{|c|c|c|c|c|c|c|}
\hline & \multirow{2}{*}{ 要因 ${ }^{1)}$} & \multirow{2}{*}{ 発病度 ${ }^{2)}$} & \multirow{2}{*}{ 腐敗率 (\%) } & \multicolumn{3}{|c|}{ 相関係数 ${ }^{3)}$} \\
\hline & & & & 抵抗性 $\times$ 発病度 & 抵抗性 $\times$ 腐敗率 & 発病度 $\times$ 腐敗率 \\
\hline \multirow[t]{6}{*}{ 品種 } & 90IDN-47（強） & 0.8 & 1.5 & \multirow{6}{*}{$-0.308 * *$} & \multirow{6}{*}{$-0.213^{*}$} & \multirow{6}{*}{$0.665^{* *}$} \\
\hline & ベニアズマ (やや強) & 3.5 & 14.0 & & & \\
\hline & コガネセンガン（中） & 3.0 & 8.7 & & & \\
\hline & ベニコマチ（やや弱～中） & 3.2 & 12.1 & & & \\
\hline & 高系 14 号（やや弱） & 3.6 & 15.2 & & & \\
\hline & 89SB-71（弱） & 4.0 & 22.7 & & & \\
\hline \multirow[t]{4}{*}{ 培養温度 $\left({ }^{\circ} \mathrm{C}\right)$} & 25.0 & 2.3 & 2.4 & $-0.304 *$ & $-0.335^{*}$ & $0.420 * *$ \\
\hline & 27.5 & 4.5 & 8.3 & $-0.627^{*}$ & -0.507 & $0.587 *$ \\
\hline & 30.0 & 3.4 & 20.5 & $-0.360 * *$ & $-0.250^{*}$ & $0.737^{* *}$ \\
\hline & 35.0 & 1.5 & 11.1 & 0.760 & 0.414 & $0.879^{*}$ \\
\hline \multirow[t]{5}{*}{ 菌体量 (g) } & 0.0 & 0.0 & 0.0 & - & - & - \\
\hline & 0.5 & 2.9 & 4.2 & -0.422 & -0.311 & 0.375 \\
\hline & 1.0 & 3.5 & 13.2 & $-0.428 * *$ & $-0.277 *$ & $0.769^{* *}$ \\
\hline & 2.0 & 2.7 & 18.6 & -0.026 & 0.010 & 0.207 \\
\hline & 5.0 & 5.0 & 12.5 & $-0.837^{*}$ & $-0.831^{*}$ & 0.573 \\
\hline \multirow[t]{2}{*}{ 培地の種類 } & 蒸留水 & 2.4 & 0.0 & -0.080 & - & - \\
\hline & ISP-2 培地 & 3.3 & 18.1 & $-0.406^{* *}$ & $-0.299 * *$ & $0.747 * *$ \\
\hline \multirow[t]{2}{*}{ 培地の量 (ml) } & 50 & 3.1 & 10.4 & $-0.416^{* *}$ & $-0.318 * *$ & $0.683 * *$ \\
\hline & 100 & 3.0 & 15.8 & -0.065 & 0.004 & $0.610^{* *}$ \\
\hline
\end{tabular}

1)括弧内は表1に同じ.

2) 発病度を塊根切断面の全体に対する病斑面積の比率に応じて0（病斑がない）９（全面が黒変または腐敗）とし，平均值を 算出した.

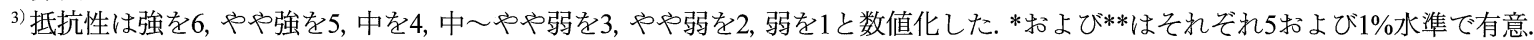

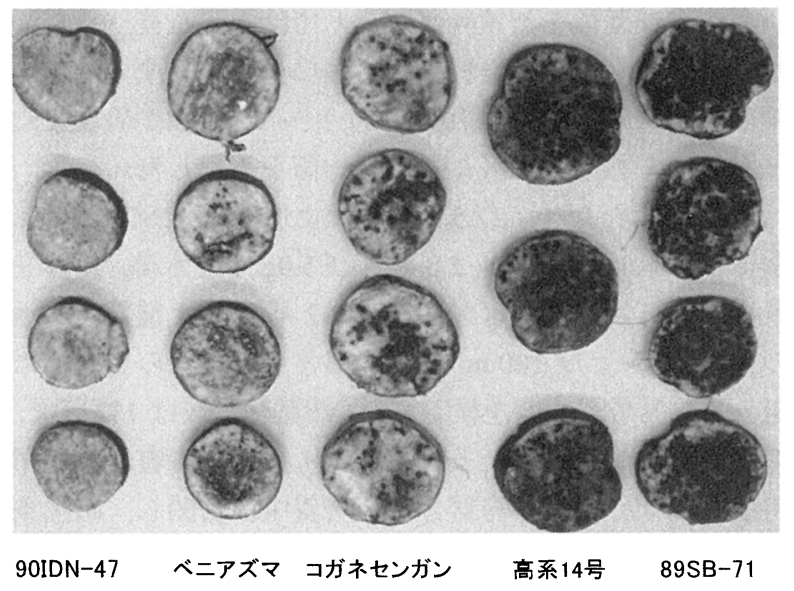

図 3. 塊根切片へのサッマイモ立枯病菌の接種による発病度の 品種間差異

ある「89SB-71」以外では腐敗が認められず，接種菌体 量も $0.5 \mathrm{~g}$ 以下であれば,「89SB-71」とやや感受性である 「ベニコマチ」でわずかに認められるに過ぎなかった.

以上の結果から，培養温度は腐敗の発生を防ぐ意味で

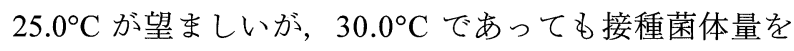
$0.5 \mathrm{~g}$ 程度にとどめることで, 検定が可能であると考えら れた. 図 4 飞, 培養温度を $25.0^{\circ} \mathrm{C}$, 接種菌体量を $1.0 \mathrm{~g}$ と したとき，扤よび培養温度を $30.0^{\circ} \mathrm{C}$ ，接種菌体量を $0.5 \mathrm{~g}$ としたときの発病度と激発戋場で判定された抵抗性の関
係を示す. 発病度は検定によって程度に差はあるものの, 激発圃場で判定された抵抗性と高い負の相関を示し, 統 計的にも一例を除き有意であった．このことから，塊根 への接種によって，サッマイモ立枯病抵抗性を判定する ことが可能であると判断された.

\section{4. おわりに}

放線菌が作物に被害を与学る例は少なく、ジャガイモ のそらか病とサッマイモ立枯病のみが報告されているに 過ぎない.ジャガイモそらか病でも放線菌密度を高めた 検定圃場での病変の発現程度を評価することで抵抗性を 判定しているが，サッマイモ立枯病と同様に年次や気象 条件によって検定結果が変動する.このため, 安定した 検定法が望まれているが，これまでのところ実用に耐兄 るものは開発されていない.

今回, サッマイモ立枯病抵抗性の検定が苗または塊根 を用いることによって室内で簡易に行兄る可能性を示し た.このことは安定的な抵抗性の評価に寄与するととも に, 育種の早期世代からの選抜による育種効率の向上を もたらすことが期待される，また，苗切片で見られたサ ッマイモ立枯病菌に対する抵抗性品種の防御反応は抵抗 性が少数の遺伝子によることをらかがわせて和り，今後 の遺伝解析に拀いて有用な情報であると考兄られた.

しかし, 試験の過程でいくつかの問題点も明らかに 
表 4. 塊根切片への接種により生じる腐敗率の品種間差異に及ぼす要因

\begin{tabular}{|c|c|c|c|c|c|c|c|}
\hline \multirow{2}{*}{ 要区 } & & \multicolumn{6}{|c|}{ 品種 } \\
\hline & & 90IDN-47 & ベニアズマ & コガネセンガン & ベニコマチ & 高系 14 号 & 89SB-71 \\
\hline \multirow{4}{*}{ 培養温度 $\left({ }^{\circ} \mathrm{C}\right)$} & 25.0 & 0.0 & 0.0 & 0.0 & 0.0 & 0.0 & 14.8 \\
\hline & 27.5 & 0.0 & 0.0 & 0.0 & 16.7 & 16.7 & 16.7 \\
\hline & 30.0 & 3.0 & 25.0 & 14.0 & 21.2 & 27.3 & 31.8 \\
\hline & 35.0 & 0.0 & 33.3 & 33.3 & 0.0 & 0.0 & 11.1 \\
\hline \multirow[t]{5}{*}{ 菌体量 (g) } & 0.0 & 0.0 & 0.0 & 0.0 & 0.0 & 0.0 & 0.0 \\
\hline & 0.5 & 0.0 & 0.0 & 0.0 & 12.5 & 0.0 & 4.2 \\
\hline & 1.0 & 0.0 & 14.6 & 7.6 & 14.6 & 17.4 & 13.2 \\
\hline & 2.0 & 6.7 & 26.7 & 20.0 & 13.3 & 20.0 & 18.6 \\
\hline & 5.0 & 0.0 & 0.0 & 0.0 & 0.0 & 25.0 & 12.5 \\
\hline
\end{tabular}

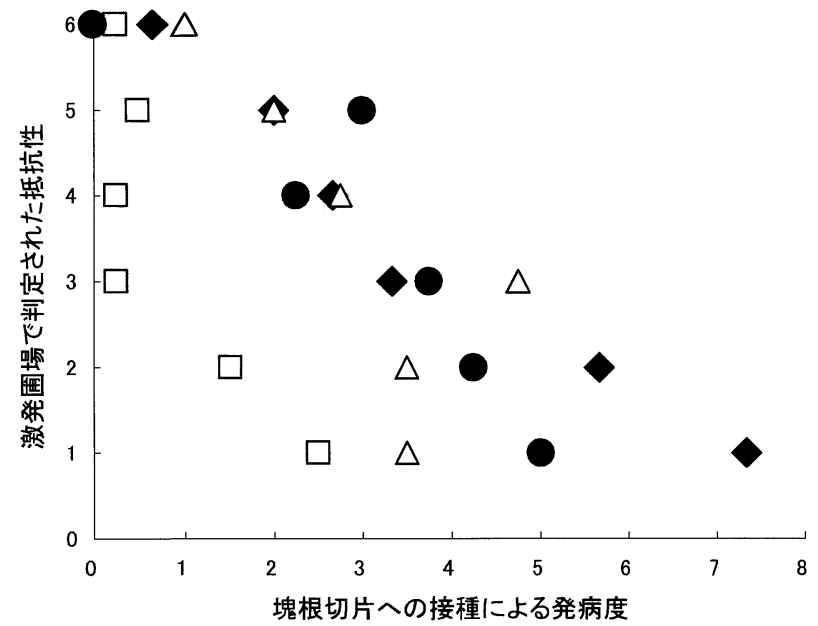

図 4. 塊根切片へのサッマイモ立枯病菌の接種による発病度と 激発畨場で判定された抵抗性との関係. 培養温度 $25^{\circ} \mathrm{C}$ ·接種菌体量 $1.0 \mathrm{~g}$ (1) $\mathrm{r}=-.977^{* *}, \square$ : 培養温度 $25^{\circ} \mathrm{C}$. 接種菌体量 $1.0 \mathrm{~g}$ (2) $\mathrm{r}=-.817^{*}, \triangle$ : 培養温度 $25^{\circ} \mathrm{C} \cdot$ 接種 菌体量 $1.0 \mathrm{~g}$ (3) $\mathrm{r}=-.775, \bigcirc$ : 培養温度 $30^{\circ} \mathrm{C} \cdot$ 接種菌体量 $0.5 \mathrm{~g} \mathrm{r}=-.913 *$. 激発围場で判定された抵抗性の数値化は 表 3 に同じ.

なった。 まず，苗および塊根のいずれに执いても培養中 の腐敗が病斑の発現程度を評価する際の障害となった. 塊根の場合はサッマイモ立枯病抵抗性との関連をらかが わせるが，「ベニアズマ」での発現が顕著であることか ら, 他の要因が関与している可能性も高い. 腐敗の原因 を明確にし，簡易検定法の改善することが必要である. 次いで，菌の毒性の低下があげられる，本研究の実施中 にも液体振とら培養を数回繰り返すと病原性が低下し, 場合によっては全く病斑を発現しなくなることが認めら れた. このため, 分離培養した元株を採取して試験に供
したが，簡易検定法を実用化する場合には菌の毒性の低 下について十分考慮することが必要である.

最近では，抵抗性であるとされてきた「ベニアズマ」 でも罹病が認められるよらになってきた.これは気象や 土壤条件の変化とともに, 菌のレース分化の可能性も否 定できない. 今回報告した苗と塊根に分けたサッマイモ 立枯病に対する反応の評価とともに，現在，作物研究所 で開発している DNA マーカーを用いることによって, レース分化の有無の解析も容易となる. このようにサッ マイモ立枯病抵抗性の簡易検定法はサッマイモ育種に抏 ける選抜のみならず様々な場面での適用が可能であり, 今後さらに改良を加えていく必要があると考㝋ている.

\section{謝 辞}

本研究を行らに当たり，サッマイモ立枯病菌を提供さ れた農業研究センタ一病害虫防除部マイコプラズマ病防 除研究室長塩見敏樹博士（現独立行政法人農業環境技術 研究所生物環境安全部微生物・小動物研究グループ長) 执よび徳島県農業試験場病虫科金磯泰雄専門研究員兼科 長（現徳島農業改良普及センタ一次長）に御礼申し上げ る.

\section{引用文献}

Moyer, J.W., C.L. Campbell, E. Echandi and W.W. Collins (1984) Phytopathology 74 (4): 493-497.

小川 奎（1984）農業および園芸 59（1）:67-72.

志賀敏夫 ·坂本 敏 - 安藤隆夫 ·石川博美 - 加藤真次郎 - 竹股知 久. 梅原正道 (1985) 農業研究センタ一研究報告 3: 73-84. 